\title{
PREVALENSI OBESITAS PADA MAHASISWA FAKULTAS KEDOKTERAN UNIVERSITAS SAM RATULANGI ANGKATAN 2011
}

\author{
Eka \\ Shane H. R. Ticoalu \\ Djon Wongkar
}

\begin{abstract}
Bagian Anatomi Histologi Fakultas Kedokteran Universitas Sam Ratulangi Manado
Email: melodyinclover@rocketmail.com
\end{abstract}

\begin{abstract}
Obesity is a condition where there are a large number of fat bodies due to some influencing factors. Recently, there has been a rising prevalency of overweight and obesity througout the world. According to the national survey in Indonesia, $8.1 \%$ of men and $13.5 \%$ of women suffered from obesity. This study aimed to find out the prevalency of obesity in medical students of Sam Ratulangi University Manado 2011. The study used a simple descriptive method to get data from body weight, body height and both calculated to BMI. Waist circumference for males is $\geq 90 \mathrm{~cm}$ and for females is $\geq 80 \mathrm{~cm}$. The results showed that of the 307 samples, $13.7 \%$ were underweight, $54.1 \%$ normal, $28 \%$ pre-obese, $3.9 \%$ obese- 1 , and $0.3 \%$ obese- 2 . Waist circumference data showed $13.5 \%$ with central obesity in males, and 4.1\% with central obesity in females. Conclusion: Among the medical students of Sam Ratulangi University Manado 2011, overweight students based on their BMI were more frequently found than those who had central obesity based on their waist circumference. However, there were some students with underweight.
\end{abstract}

Keywords: obesity, overweight, BMI, waist circumference.

\begin{abstract}
Abstrak: Obesitas adalah peningkatan lemak tubuh yang dapat terjadi oleh beberapa faktor. Beberapa tahun terkhir ini, terjadi peningkatan prevalensi kelebihan berat badan (overweight) dan obesitas diseluruh dunia. Berdasarkan survei nasional di Indonesia, 8,1\% laki-laki di indonesia menderita obesitas dan $13,5 \%$ perempuan. Tujuan penelitian untuk mengetahui prevalensi obesitas pada mahasiswa Fakultas Kedokteran Universitas Sam Ratulangi Manado angkatan 2011. Penelitian ini menggunakan metode deskriptif dimana diperoleh data melalui pengukuran berat badan, tinggi badan yang akan dihitung dengan menggunakan rumus IMT dan lingkar perut dengan kriteria laki-laki $\geq 90 \mathrm{~cm}$ dan perempuan $\geq 80 \mathrm{~cm}$ pada 307 populasi mahasiswa Fakultas Kedokteran Universitas Sam Ratulangi Angkatan 2011. Hasil penelitian memperlihatkan $13,7 \%$ underweight, $54,1 \%$ normal, $28 \%$ pre-obes, 3,9\% obes 1 , dan $0,3 \%$ obes 2. Penelitian yang dilakukan melalui pengukuran lingkar perut diperoleh 13,5\% laki-laki dengan obesitas sentral dan 4,1\% perempuan dengan obesitas sentral. Simpulan: Mahasiswa/i Fakultas Kedokteran Universitas Sam Ratulangi Angkatan 2011 dengan kelebihan berat badan (overweight) melalui perhitungan IMT lebih sering ditemukan daripada yang dengan obesitas sentral melalui pengukuran lingkar perut; walaupun demikian, mahasiswa/i dengan underweight juga ditemukan.
\end{abstract}

Kata kunci: obesitas, overweight, IMT, lingkar perut.

Obesitas adalah peningkatan lemak tubuh yang dapat terjadi oleh berbagai faktor. Penemuan terbaru yang berkaitan dengan penyebab obesitas menyebabkan patogenesis obesitas terus berkembang. Terjadinya obesitas secara umum, berkaitan dengan 
keseimbangan energi didalam tubuh. Keseimbangan energi ditentukan oleh asupan energi yang berasal dari karbohidrat, lemak dan protein. ${ }^{1}$

Obesitas merupakan ketidakseimbangan energi dimana asupan energi yang diperoleh dari makanan melampaui kebutuhan energiyang diperlukan. Banyak faktor yang menunjang kelebihan ini, namun dapat disederhanakan menjadi terlalu banyak makan, terlalu sedikit bergerak. Diet kini makin terbukti sebagai kontributor utama obesitas. ${ }^{2}$

Berkurangnya pergerakan fisik tidak lain didorong oleh kemajuan teknologi. Penggunaan robot dalam industri telah menggiring manusia untuk tidak mau bersusah payah. Banyak penelitian membuktikan bahwa prevalensi obesitas dan nilai indeks massa tubuh menyusut ketika olahraga digiatkan. ${ }^{2} \mathrm{Hal}$ ini meningkatkan prevalensi penderita obesitas, di Amerika Serikat lebih dari 50\% orang dewasa dan lebih dari 25\% anak-anak menderita obesitas. Berdasarkan survei Nasional di Indonesia 8,1\% laki-laki di Indonesia penderita obesitas dan13,5\% perempuan obesitas. Obesitas dapat disebabkan oleh karena ketidakseimbangan antara asupan energi dengan energi yang digunakan, ini dipengaruhi oleh aktivitas fisik, pola makan dan lingkungan. ${ }^{1}$

Beberapa tahun terakhir ini, terjadi peningkatan prevalensi overweight atau kelebihan berat badan dan obesitas di seluruh dunia sebagai konsekuensi dari meningkatnya perkembangan ekonomi di negara-negara Asia Pasifik. Kejadian obesitas ini menggambarkan suatu peningkatan asupan kalori yang tinggi disertai penurunan aktivitas fisik. Lebih dari 1,1 milyar orang diperkirakan mengalami kelebihan berat badan dan 320 juta diantaranya dikategorikan sebagai obesitas. The International Obesity Task Force (IOTF) memperkirakan lebih dari 1,7 milyar orang memiliki risiko kesehatan yang berhubungan dengan berat badan, termasuk populasi di Asia, dengan Indeks Massa Tubuh (IMT) $\geq 23$. $^{(1,2)}$

Berdasarkan survei Nasional di Indo- nesia, 8,1\% laki-laki di Indonesia penderita obesitas dan $13,5 \%$ perempuan. ${ }^{1}$ Keadaan inilah yang menjadi perhatian peneliti, sehingga mengambil judul ini.

\section{TUJUAN}

Untuk mengetahui angka kejadian obesitas pada mahasiswa kedokteran angkatan 2011 dengan menggunakan pengukuran berat badan, tinggi badan yang akan dihitung sebagai Indeks Massa Tubuh (IMT), diamping itu mengetahui angka kejadian obesitas pada mahasiswa kedokteran angkatan 2011 dengan menggunakan pengukuran lingkar perut.

\section{OBESITAS}

Terdapat beberapa istilah yang perlu diketahui, yaituoverweight, dan obesitas sentral. Obesitas adalah peningkatan lemak tubuh. Untuk menentukan seseorang dengan berat badan tubuh yang kurang, ideal ataupun lebih digunakan pengukuran Indeks Masa Tubuh (IMT),yaitu berat badan (kilogram) dibagi tinggi badan dalam kuadrat $\left(\mathrm{m}^{2}\right)^{1,3}$

Normalnya IMT berkisar antara 18,522,9 , sedangkan IMT yang $\geq 23$ dikatakan overweight, 23-29,9pre-obese, 30-34,9 tergolong obese I dan 35-39,9 dikatan obese II, dan obese $I I I \geq 40$. $^{2}$

Obesitas bukan suatu penyakit yang terjadi dengan sendirinya tetapi merupakan suatu kompleks gejala dengan berbagai korelasinya naiknya angka mortalitas, penyakit kardiovaskuler, arterosklerosis, dan frekuensi diabetes. Obesitas ini dipengaruhi oleh peningkatan nafsu makan, dimana peningkatan nafsu makan ini dipengaruhi oleh berbagai faktor psikologi dan hiperinsulin. ${ }^{3}$

Obesitas disebabkan karena konsumsi makanan yang jauh melebihi kebutuhan. Angka kejadian obesitas pada usia remaja dan anak yang semula 10-30 \% dari penderita obesitas dewasa di negara maju diperkirakan terus bertambah. Adapun pertambahan ini dipengaruhi oleh faktor lingkungan dan genetik. $^{20}$

Faktor genetik berperan penting untuk 
memicu timbulnya obesitas. Bila salah satu orang tua mengalami obesitas, maka anaknya memiliki kecenderungan mengalami obesitas sebesar $40 \%$. Bila kedua orang tua mengalami obesitas, maka kecenderungan anaknya untuk menjadi obesitas sebesar $80 \% .^{20}$

Secara klinis obesitas dengan mudah dapat dikenali karena mempunyai tanda dan gejala yang khas, antara lain wajah yang membulat, dagu rangkap, leher relatif pendek, dada yang membusung dengan payudara yang membesar mengandung jaringan lemak, perut membuncit diserta dinding perut yang berlipatlipat serta kedua tungkai umumnya berbentuk $\mathrm{X}$ dengan kedua pangkal paha bagian dalam saling menempel dan bergesekan akibatnya menyebabkan laserasi dan ulserasi yang dapat menimbulkan bau yang kurang sedap. Pada anak lelaki, penis tampak kecil karena tersembunyi dalam jaringan lemak suprapubik (burried penis), hal yang seringkali menyebabkan orang tua menjadi sangat khawatir dan segera membawanya ke dokter. ${ }^{8}$

Obesitas ini akrab dengan semua negara industri, dimana pervalensinya mencapai $1 / 4$ dari populasi dewasa. Obesitas ini sangat mempengaruhi kebiasaan, apalagi pada anak-anak dengan usia remaja. Tentunya dengan peningkatan berat badan yang berlebihan menyebabkan gangguan psikologi anak,nantinya akan cenderung minder karena penampilannya kurang memuaskan. ${ }^{4}$ Selain mengganggu penampilan obesitas ini tentu dapat menyebabkan berbagai penyakit metabolik ataupun penyakit-penyakit kardiometabolik. Prevalensi peningkatan penyakit jantung kini semakin meningkat, hal ini disebabkan oleh karena peningkatan kadar kolestrol yang akrab dengan para obesitas. $^{5}$

\section{Jaringan lemak dan sel lemak}

Jaringan lemak merupakan depot penyimpanan energi paling besar bagi mamalia. Tugas utamanya adalah untuk menyimpan energi dalam bentuk trigliserid melalui proses lipogenesis. Sel lemak dan jaringan lemak ini sangat penting dalam penyimpanan energi yang merupakan sumber energi utama sesudah karbohidrat, namun apabila asupan makanan yang nantinya akan di bentuk menjadi energi itu berlebihan tanpa diringi dengan pembakaran energi, nantinya akan menyebakan terjadinya obesitas. ${ }^{7}$

Pemahaman mengenai nutrisi transkripsional lipogenesis telah berkembang pesat dalam proses metabolisme lemak. Lipogenesis dirangsang oleh diet tinggi karbohidrat, namun juga dapat dihambat oleh asam lemak tak ganda dan dengan berpuasa. Diet tinggi karbohidrat dan makanan yang tinggi lemak menyebabkan terjadinya penumpukan lemak pada jarinan adiposa yang berakibat penumpukan lemak baik di perifer maupun sentral. Hormon pertumbuhan memegang peranan peting dalam menurunkan lipogenesis di jaringan adipose ini. Hormon pertumbuhan ini dapat menurunkan sinyal insulin dan dapat menurunkan akumulasi lemak pada jaringan adiposa yang nantinya lemak ini akan dirubah menjadi masa otot. Selain berbagai faktor diatas leptin juga berpengaruh dalam membatasi penyimpanan lemak. ${ }^{7}$

Jika dipandang dari sisi anatomi, berat badan merupakan akumulasi sepanjang hidup dari enam elemen utama, yaitu: oksigen, karbon, hidrogen, nitrogen, kalsium dan fosfor. ${ }^{7}$

\section{Prevalensi obesitas}

Prevalensi obesitas pada anak usia 617 tahun di Amerika Serikat dalam tiga dekade terakhir meningkat dari 7,6-10,8\% menjadi $13-14 \%$. Prevalensi overweight dan obesitas pada anak usia 6-18 tahun di Rusia adalah $6 \%$ dan $10 \%$, di Cina adalah $3,6 \%$ dan 3,4\%, dan di Inggris yaitu 22$31 \%$ dan $10-17 \%$, bergantung pada umur dan jenis kelamin. Prevalensi obesitas pada anak-anak sekolah di Singapura meningkat dari $9 \%$ menjadi $19 \%{ }^{6}$

Di Indonesia, prevalensi obesitas pada balita menurut survei sosial ekonomi nasional (SUSENAS) menunjukkan peningkatan baik di perkotaan maupun pedesaan. Di perkotaan pada tahun 1989 didapatkan 4,6\% lelaki dan 5,9\% perempuan. Pada tahun 1992 didapatkan 6,3\% lelaki dan 8\% untuk perempuan. Prevalensi obesitas tahun 1995 di 27 propinsi adalah 4,6\%. ${ }^{6}$ 
Di Jakarta, prevalensi obesitas meningkat dengan bertambahnya umur. Pada umur 6-12 tahun ditemukan obesitas sekitar $4 \%$, pada anak remaja 12-18 tahun ditemukan 6,2\%, dan pada umur 17-18 tahun $11,4 \%$. Kasus obesitas pada remaja lebih banyak ditemukan pada wanita (10,2\%) dibanding lelaki (3,1\%).Pada penelitian Djer 1998, prevalensi obesitas anak di sebuah sekolah dasar(SD) Negeri di kawasan Jakarta Pusat sebesar 9,6\%. Penelitian yang dilakukan oleh Meilany 2002, menunjukkan prevalensi obesitas anak di tiga SD swasta di kawasan Jakarta Timur sebesar 27,5\%. Menurut data rekam medik, kasus baru obesitas yang datang di poliklinik Gizi Anak Bagian Ilmu Kesehatan Anak (IKA)Fakultas Kedokteran Univrsitas Indonesia dalam periode tahun 1995-2000 adalah sebanyak 100 pasien, densitas Indonesia 35\% di antaranya adalah balita. ${ }^{6}$

Saat ini, 1,6 miliar orang dewasa di seluruh dunia mengalami berat badan berlebih (overweight), dan sekurangkurangnya 400 juta diantaranya mengalami obesitas. Pada tahun 2015, diperkirakan 2,3 miliar orang dewasa akan mengalami overweight dan 700 juta di antaranya obesitas. Di Indonesia, menurut data Riset Kesehatan Dasar (Riskesdas) tahun 2007, prevalensi nasional obesitas umum pada penduduk berusia $>=15$ tahun adalah 10,3\% (laki-laki 13,9\%, perempuan $23,8 \%$ ). Sedangkan prevalensi berat badan berlebih anak-anak usia 6-14 tahun pada laki-laki 9,5\% dan pada perempuan 6,4\%. Angka ini hampir sama dengan estimasi WHO sebesar $10 \%$ pada anak usia 5-17 tahun. $^{21}$

Melihat angka pervalensi remaja dengan obesitas tentunya menjadi perhatian khusus karena remaja merupakan generasi penerus bangsa. Remaja merupakan sasaran empuk obesitas hal ini disebabkan karena adanya perubahan budaya, yang bergeser dari budaya timur ke budaya barat. Kebiasaan budaya timur yang memanfaatkan makanan-makanan alam sebagai sumber utama yang seimbang antara karbohidrat, lemak, dan protein untuk kebutuhan sehari-hari kini mulai bergeser ke makanan-makanan yang bersifat siap saji, dimana makanan-makanan ini memiliki kadar lemak yang tinggi. ${ }^{1}$

Obesitas didefisinikan sebagai kelebihan lemak tubuh. Prevalensi obesitas akhirakhir ini meningkat karena meningkatnya asupan kalori dari makanan, minuman bergula tinggi, lemak, gaya hidup sedenter, menurunnya aktivitas fisik, serta berbagai kecanggihan teknologi yang ada. Obesitas biasanya dinyatakan melalui Indeks Massa Tubuh(IMT) yaitu berat badan (kilogram) dibagi tinggi badan dalam kuadrat $\left(\mathrm{m}^{2}\right)$. Menurut World Health Organization (WHO), BMI yang berkisar $25-29 \mathrm{~kg} / \mathrm{m}^{2}$ termasuk dalam kriteria Overweight sementara $\mathrm{BMI} \geq 30 \mathrm{~kg} / \mathrm{m}^{2}$ termasuk ke dalam kriteria obes. Secara klinis penentuan obesitas dapat dilakukan dengan menentukan lingkar perut karena kelebihan lemak abdominal terkait erat dengan faktor risiko sindrom metabolik. ${ }^{13}$

Sindrom metabolik (SM) yang sangat berkaitan dengan diabetes mellitus (DM) tipe 2 dan penyakit jantung koroner, merupakan sekumpulan gejala penyakit yang kompleks dan kronis dengan ciri adanya perburukan metabolism. ${ }^{14}$

Sebanyaknya $25 \%$ populasi dewasa di dunia diperkirakan mempunyai sindrom ini. Mereka yang menderita SM mempunyai risiko kematian dua kali lipat melalui penyakit jantung atau stroke dan tiga kali lebih besar terkena penyakit ini dibandingkan dengan orang tanpa SM. ${ }^{15}$

Pada tahun 1998, Albertini dan Zimmet atas nama WHO mendifinisikan kriteria sindroma $\mathrm{X}$ dan merubah namanya menjadi SM. Perubahan ini dilakukan mengingat peranan obesitas dalam disfungsi metabolik. Kriteria SM dari WHO adalah individu tersebut harus mengalami diabetes, gangguan pengaturan glukosa atau mengalami resistensi insulin, ditambah dua atau lebih kriteria berikut :

1. Tekanan darah tinggi $\geq 140 / 90 \mathrm{mmHg}$.

2. Hiperlipidemia, yaitu peningkatan trigliserida $\geq 150 \mathrm{mg} / \mathrm{dL}$ dan atau kolesterol $\mathrm{HDL}<35 \mathrm{mg} / \mathrm{dL}$ pada pria 
dan $<39 \mathrm{mg} / \mathrm{dL}$ pada wanita.

3. Obesitas sentral : waist to hip ratio $>$ 0,90 untuk pria dan $>0,85$ untuk wanita dan atau IMT $\geq 30 \mathrm{~kg} / \mathrm{m}^{2}$.

4. Mikroalbuminuria : urinary albumin excretion rate $\geq 20 \mathrm{mmg} / \mathrm{min}$ atau rasio albumin/kreatinin $\geq 20 \mathrm{mg} / \mathrm{g}^{16}$

Pada tahun 2001 National Cholesterol Education Program Adult Treatment Panel (NCEP-ATP III) mendifinisikan SM secara berbeda, memodifikasi kriteria glukosa darah puasa dan menganjurkan pengukuran glukosa darah 2 jam setelah pemberian glukosa oral, serta pengukuran lingkar perut menggantikan indeks massa tubuh (IMT), sehingga kriteria SM menurut NCEP-ATP III adalah sebagai berikut: ${ }^{17}$

1. Obesitas sentral (lingkar perut pria $>$ $102 \mathrm{~cm}$ dan lingkar perut wanita $>88$ $\mathrm{cm})$.

2. Trigliserida $>150 \mathrm{mg} / \mathrm{dL}$ atau sedang dalam pengobatan spesifik untuk abnormalitas lemak.

3. Kolesterol HDL priá $40 \mathrm{mg} / \mathrm{dL}$, wanita $<50 \mathrm{mg} / \mathrm{dL}$ atau sedang dalam pengobatan spesifik untuk abnormalitas lemak.

4. Tekanan darah $\geq 130 / 85 \mathrm{mmHg}$ atau pernah didiagnosis hipertensi.

5. Glukosa darah puasa $>110 \mathrm{mg} / \mathrm{dL}$ atau telah didiagnosis diabetes mellitus tipe 2 sebelumnya.

Menurut IDF - 2005, kriteria SM adalah: pasien harus menderita obesitas sentral (lingkar perut pria untuk Asia Pasifik $\geq 90$ $\mathrm{cm}$ dan wanita $\geq 80 \mathrm{~cm}$, kecuali untuk Jepang $\geq 90 \mathrm{~cm}$. Selain itu ditambah 2 dari 4 faktor berikut: ${ }^{18}$

1. Trigliserida $>150 \mathrm{mg} / \mathrm{dL}$ atau sedang dalam pengobatan spesifik untuk menurunkan lipid.

2. Kolesterol HDL pría $40 \mathrm{mg} / \mathrm{dL}$, wanita $<50 \mathrm{mg} / \mathrm{dL}$ atau sedang dalam pengobatan spesifik untuk menurunkan lipid.

3. Tekanan darah $>130 / 85 \mathrm{mmHg}$ atau pernah didiagnosis hipertensi.

4. Glukosa darah puasa $>100 \mathrm{mg} / \mathrm{dL}$ atau telah didiagnosis diabetes mellitus tipe 2 sebelumnya.

\section{Dampak klinis obesitas}

Pertambahan massa lemak selalu disetai perubahan fisiologis tubuh yang sebagian besar bergantung pada distribusi regional massa lemak itu. Obesitas menyeluruh mengakibatkan perubahan volume darah total serta fungsi jantung. Sementara penyebaran regionaldisekitar rongga perut dan dada akan menyebabkan gangguan fungsi respirasi. Timbunan lemak pada jaringan viseral (intra-abdomen), yang tergambar sebagai penambahan ukuran lingkar perut, akan mendororng perkembangan hipertensi, peningkatan kadar insulin plasma, sindrom resistensi insulin, hipertrigliseridemia, dan hiperlipidemia. Gangguan klinis yang ditimbulkanoleh obesitas meliputi DM tipe 2, sindrom resistensi insulin, perubahan fungsi kardiovaskuler, gangguan homeostasis, penyimpangan pola tidur, fungsi reproduksi dan fungsi hati, pembentukan batu empedu, peningkatan resiko terhadap kanker tertentu, osteoarthritis, serta komplikasi lain. ${ }^{2}$

Obesitas adalah salah satu faktor risiko stroke. Obesitas yaitu istilah yang digunakan untuk menunjukkan adanyakelebihan berat badan. Kata obesitas berasal dari bahasa latin yang berarti makan berlebihan. Obesitas merupakanmasalah yang kompleks, dengan penyebab yang bersifat multifaktorial. Pada kelompok anak, remaja, dan dewasamuda, obesitas akan berpengaruh pula pada perkembangan psikososial. Berbagai penelitian menunjukkan peningkatan kecenderungan bunuh diri pada anak/ remaja yang obesitas. Obesitas secara konsisten dihubungkan pula dengankematian dini, penyakit jantung, hipertensi, diabetes, dan stroke. ${ }^{22}$

\section{METODE PENELITIAN}

Penelitian yang dilakukan bersifat deskriptif yang dilakukan di Fakultas Kedokteran Universitas Sam Ratulangi selama dua puluh empat hari. Populasi penelitian 
adalah seluruh mahasiswa Fakultas Kedokteran Universitas Sam Ratulangi angkatan 2011. Variabel bebas berupa tinggi badan dan berat badan, variabel terikat berupa Indeks Massa Tubuh dan lingkar perut.

\section{Definisi operasional}

1. Obesitas merupakan peningkatan lemak tubuh. $^{19}$ Untuk menentukan seseorang dengan berat badan tubuh yang kurang, ideal ataupun lebih digunakan pengukuran Indeks Masa Tubuh (IMT), dengan rumus berat badan (kilogram) dibagi tinggi badan dalam kuadrat $\left(\mathrm{m}^{2}\right) .{ }^{13}$ Normalnya IMT berkisar diantara 18,5-22,9, sedangkan IMT yang $\geq$ 23 dikatakan overweight, 23-29,9preobese, 30-34,9 tergolong obese 1 dan 35-39,9 dikatan obese II, dan obese III $\geq 40{ }^{2}$

2. Berat badan yaitu parameter yang memberikan gambaran massa tubuh yang sensitif terhadap perubahan-perubahan yang mendadak dan parameter antropometri yang sangat labil. ${ }^{9}$

3. Tinggi badan yaitu antropometri yang menggambarkan keadaan pertumbuhan skeletal yang pada keadaan normal tinggi badan tumbuh seiring dengan pertambahan umur. ${ }^{9}$

4. Lingkar perut yaitu gambaran lemak tubuh tidak termasuk sebagian besar berat tulang kecuali tulang belakang. ${ }^{11}$

\section{Alat dan bahan}

Alat dan bahan yang digunakan ialah timbangan badan, alat pengukur tinggi badan (stature meter), meteran pengukur lingkar perut, kertas untuk pencatatan hasil pengukuran tinggi badan dan berat badan.

\section{Prosedur Penelitian}

1. Izin penelitian dari pimpinan Fakultas Kedokteran Universitas Sam Ratulangi.

2. Mengumpulkan seluruh mahasiswa Fakultas Kedokteran Universitas Sam Ratulangi angkatan 2011.

3. Memberikan lembar persetujuan penelitian kepada subyek penelitian.
4. Mengukur berat badan mahasiswa dan mahasiswi Fakultas Kedokteran Universitas Sam Ratulangi angkatan 2011 dengan cara timbangan badan diletakkan di tempat datar. Pastikan angka pada timbangan berada pada angka 0,0. Subyek yang akan diukur ditimbang tanpa mengunakan alas kaki. Menggunakan pakaian seminimal mungkin. Angka yang terlihat sejajar dengan jarum penunjuk adalah berat badan dari subyek yang diukur. ${ }^{2}$

5. Mengukur tinggi badan mahasiswa dan mahasiswi Fakultas Kedokteran Universitas Sam Ratulangi angkatan 2011 dengan cara tempelkan alat pengukur tinggi badan (stature meter) pada dinding lurus, datar setinggi 2 meter. Angka 0 (nol) pada lantai yang datar. Lepaskan sepatu. Subyek yang akan diukur berdiri tegak seperti sikap siap sempurna. Kaki lurus, tumit, pantat, punggung dan kepala bagian belakang harus menempel pada dinding dan wajah menghadap lurus dengan pandangan ke depan. Turunkan alat pengukur tinggi badan (stature meter) sampai rapat pada kepala bagian atas, sikusiku harus lurus menempel pada dinding. Baca angka pada skala yang Nampak pada lubang dalam gulungan alat pengukur tinggi badan (stature meter). Angka tersebut menunjukkan tinggi badan yang diukur. ${ }^{9}$

6. Lingkar perut diukur pada pertengahan antara batas bawah iga dan krista iliaka dengan menggunakan ukuran pita secara horisontal pada saat akhir ekspirasi dengan kedua tungkai dilebarkan 20-30 $\mathrm{cm}$. Subyek diminta untuk tidak menahan perutnya dan diukur memakai pita pengukur. ${ }^{11}$

\section{Pengolahan Data}

Setelah dilakukan pengurukuran tinggi badan dan berat badan, dihitung Indeks Massa Tubuh (IMT) dari subyek penelitian yaitu berat badan (kilogram) dibagi tinggi badan dalam kuadrat $\left(\mathrm{m}^{2}\right)$.

Kemudian data-data yang sudah di- 
peroleh, yaitu umur, jenis kelamin, berat badan, tinggi badan, IMT dan lingkar perut dianalisis menggunakan software SPSS.

\section{HASIL PENELITIAN}

\section{Karakteristik Subyek Penelitian}

Subyek penelitian yang diteliti yaitu seluruh mahasiswa Fakultas Kedokteran Universitas Sam Ratulangi angkatan 2011 yang berjumlah 307 orang, yang terdiri dari 111 (36,2\%) laki-laki dan 196 (63,8\%) perempuan berumur 16 - 20 tahun.

\section{Karakteristik berdasarkan jenis kelamin}

Pada tabel 1 dapat dilihat karakteristik berdasarkan jenis kelamin pada subyek penelitian.

Tabel 1. Karakteristik berdasarkan jenis kelamin.

\begin{tabular}{ccc}
\hline $\begin{array}{c}\text { Jenis } \\
\text { Kelamin }\end{array}$ & Frekuensi & $\begin{array}{c}\text { Persentasi } \\
\mathbf{( \% )}\end{array}$ \\
\hline Laki-laki & 111 & 36,2 \\
Perempuan & 196 & 63,8 \\
\hline Total & $\mathbf{3 0 7}$ & $\mathbf{1 0 0}$ \\
\hline
\end{tabular}

\section{Karakteristik berdasarkan umur}

Pada tabel 2 dapat dilihat karakteristik berdasarkan umur pada subyek penelitian.

Tabel 2. Karakteristik berdasarkan umur.

\begin{tabular}{ccc}
\hline Umur & Frekuensi & Persentasi (\%) \\
\hline 16 & 2 & 0,7 \\
17 & 117 & 38,1 \\
18 & 164 & 53,4 \\
19 & 21 & 6,8 \\
20 & 3 & 1 \\
\hline Total & $\mathbf{3 0 7}$ & $\mathbf{1 0 0}$ \\
\hline
\end{tabular}

\section{INDEKS MASSA TUBUH}

Berdasarkan penelitian yang dilakukan secara deskriptif kepada 307 subyek penelitian diperoleh hasil indeks massa tubuh (IMT) melalui pengukuran tinggi badan dan berat badan pada tabel 3 .

Hasil yang diperoleh menunjukkan dari 307 subyek penelitian terdapat 13,7\% underweight, 54,1\% normal, 28\% preobese, Obese I sebesar 3,9\%, dan obese II $0,3 \%$.

Tabel 3. Hasil pengukuran Indeks Massa Tubuh (IMT).

\begin{tabular}{cccc}
\hline Kriteria & IMT & Frekuensi & Persentasi (\%) \\
\hline Underweight & $<18,5$ & 42 & 13,7 \\
Normal & $18,5-22,9$ & 166 & 54,1 \\
Pre-obese & $23-29,9$ & 86 & 28 \\
Obese 1 & $30-34,9$ & 12 & 3,9 \\
Obese 2 & $35-39,9$ & 1 & 0,3 \\
Obese 3 & $\geq 40$ & 0 & 0 \\
\hline Total & & $\mathbf{3 0 7}$ & $\mathbf{1 0 0}$ \\
\hline
\end{tabular}

Tabel 4. Hasil Pengukuran Indeks Massa Tubuh (IMT) pada laki-laki.

\begin{tabular}{cccc}
\hline Kriteria & IMT & Frekuensi & Persentasi (\%) \\
\hline Underweight & $<18,5$ & 7 & 6,3 \\
Normal & $18,5-22,9$ & 53 & 47,7 \\
Pre-obese & $23-29,9$ & 43 & 38,7 \\
Obese 1 & $30-34,9$ & 7 & 6,3 \\
Obese 2 & $35-39,9$ & 1 & 9 \\
Obese 3 & $\geq 40$ & 0 & 0 \\
\hline Total & & $\mathbf{1 1 1}$ & $\mathbf{1 0 0}$ \\
\hline
\end{tabular}


S90 Jurnal Biomedik, Volume 4, Nomor 3, Suplemen, November 2012, hlm. S83-92

Tabel 5. Hasil Pengukuran Indeks Massa Tubuh (IMT) pada perempuan.

\begin{tabular}{cccc}
\hline Kriteria & IMT & Frekuensi & Persentasi (\%) \\
\hline Underweight & $<18,5$ & 35 & 17,9 \\
Normal & $18,5-22,9$ & 113 & 57,7 \\
Pre-obese & $23-29,9$ & 43 & 21,9 \\
Obese 1 & $30-34,9$ & 5 & 2,6 \\
Obese 2 & $35-39,9$ & 0 & 0 \\
Obese 3 & $\geq 40$ & 0 & 0 \\
\hline Total & & $\mathbf{1 9 6}$ & $\mathbf{1 0 0}$ \\
\hline
\end{tabular}

Tabel 6. Indeks Massa Tubuh (IMT) berdasarkan umur.

\begin{tabular}{cccc}
\hline Umur & IMT & Jumlah & Persentasi (\%) \\
\hline 16 tahun & Normal & 2 & 0,6 \\
\hline 17 tahun & Underweight & 15 & 4,8 \\
& Normal & 66 & 21,4 \\
& Pre-obese & 33 & 10,7 \\
& Obese 1 & 3 & 0,9 \\
\hline \multirow{2}{*}{18 tahun } & Underweight & 23 & 7,4 \\
& Normal & 86 & 28,01 \\
& Pre-obese & 45 & 14,6 \\
& Obese 1 & 9 & 2,9 \\
& Obese 2 & 1 & 0,3 \\
\hline \multirow{2}{*}{19 tahun } & Underweight & 4 & 1,3 \\
& Normal & 10 & 3,2 \\
& Pre-obese & 7 & 2,2 \\
\hline 20 tahun & Normal & 2 & 0,6 \\
& Pre-obese & 1 & 0,3 \\
\hline Total & & $\mathbf{3 0 7}$ & $\mathbf{1 0 0}$ \\
\hline
\end{tabular}

Tabel 7. Hasil pengukuran lingkar perut subyek dengan obesitas.

\begin{tabular}{cccc}
\hline Kriteria & Lingkar Perut & Frekuensi & Persentasi (\%) \\
\hline Obesitas & Laki-Laki $: \geq 90 \mathrm{~cm}$ & 15 & 13,5 \\
& Perempuan $: \geq 80 \mathrm{~cm}$ & 8 & 4,1 \\
\hline Total & & $\mathbf{2 3}$ & $\mathbf{1 7 , 6}$ \\
\hline
\end{tabular}

Berdasarkan karakteristik jenis kelamin, didapatkan 6,3\% underweight, 47,7\% normal, 38,7\% pre-obese, Obese I sebesar 6,3\%, dan obese II 9\% untuk laki-laki (tabel 4). Dan untuk perempuan didapatkan 17,9\% underweight, 57,7\% normal, 21,9\% pre-obese, Obese I sebesar 2,6\% seperti pada tabel 5.

Berdasarkan kriteria umur, didapatkan 6,3\% underweight, 47,7\% normal, 38,7\% pre-obese, Obese I sebesar 6,3\%, dan obese II 9\% untuk laki-laki (tabel 6).

\section{LINGKAR PERUT}

Berdasarkan penelitian yang dilakukan secara deskriptif kepada 307 subyek penelitian diperoleh hasil pengukuran lingkar perut seperti pada tabel 7 .

Hasil yang diperoleh menunjukkan dari 307 subyek penelitian terdapat 13,5\% laki-laki obesitas sentral dan 4,1\% perempuan dengan obesitas sentral.

\section{BAHASAN}

Penelitian ini dilakukan di Fakultas 
Kedokteran Universitas Sam Ratulangi angkatan 2011 dengan subyek penelitian berjumlah 307 mahasiswa, yang terdiri dari 111 (36,2\%) orang laki-laki dan 196 (63,8\%) orang perempuan.Subyek penelitian mempunyai karakteristik usia 16-20 tahun, dengan frekuensi terbanyak mahasiswa berumur 18 tahun, yaitu 164 (53,4\%) orang, diikuti dengan 117 (38,1\%) orang mahasiswa berumur 17 tahun, 21 $(6,8 \%)$ mahasiswa berumur 19 tahun, 3 (1\%) mahasiswa berumur 20 tahun dan 2 $(0,7 \%)$ mahasiswa berumur 16 tahun.

Berdasarkan penelitian yang dilakukan, diperoleh hasil dari 307 subyek penelitian melalui perhitungan IMT terdapat 13,7\% underweight, 54,1\% normal, dan $32,2 \%$ overweight.Dari 32,2\% overweight, terdiri dari28\% pre-obese, 3,9\% Obese I sebesar, dan obese II 0,3\%.

Berdasarkan jenis kelamin, pada lakilaki didapatkan 6,3\% underweight, 47,7\% normal, dan $54 \%$ overweight yang terdiri dari 38,7\% pre-obese, Obese I sebesar 6,3\%, dan obese II 9\%. Pada perempuan didapatkan 17,9\% underweight, 57,7\% normal, dan $24,5 \%$ overweight, yang terdiri atas $21,9 \%$ pre-obese, Obese I sebesar $2,6 \%$.

Obesitas didefinisikan sebagai kelebihan lemak tubuh. Prevalensi obesitas akhirakhir ini meningkat karena meningkatnya asupan kalori dari makanan, minuman bergula tinggi, lemak, gaya hidup sedenter, menurunnya aktivitas fisik, serta berbagai kecanggihan teknologi yang ada. ${ }^{13}$

Peningkatan Prevalensi obesitas berkaitan erat dengan meningkatnya prevalensi kejadian sindroma metabolik (SM). ${ }^{13}$ Pengertian sindroma metabolik (SM) secara singkat adalah sekumpulan gejala penyakit yang kompleks dan kronis dengan ciri adanya perburukan metabolisme. Berbagai organisasi memberikan definisi yang berbeda terhadap SM. Walaupun demikian seluruh kelompok studi tersebut sependapat bahwa obesitas sentral, resistensi insulin, dislipidemia dan hipertensi merupakan komponen utama SM. ${ }^{14}$

Secara klinis penentuan obesitas dapat dilakukan dengan menentukan lingkar pe- rut karena kelebihan lemak abdominal terkait erat dengan faktor risiko sindrom metabolik. $^{13}$

Dari pengukuran lingkar perut di dapatkan hasil 13,5\% laki-laki obesitas sentral dan 4,1\% perempuan. Kriteria obesitas sentral untuk laki-laki $\geq 90 \mathrm{~cm}$ dan perempuan $\geq 80 \mathrm{~cm}$.

Hal ini menunjukkan dari perhitungan IMT terdapat 32,2\% yang beresiko terjadinya sindrom metabolik dan dari pengukuran lingkar perut, terdapat $13,5 \%$ lakilaki obesitas sentral dan 4,1\% perempuan.

\section{SIMPULAN}

Berdasarkan hasil penelitian yang dilakukan terhadap mahasiswa fakultas kedokteran universitas sam ratulangi angkatan 2011, dapat ditarik kesimpulan sebagai berikut:

1. Dari penghitungan indeks massa tubuh, diperoleh sebanyak 32,2 \% mahasiswa yang memiliki berat badan lebih atau overweight, yaitu dari 307 subyek penelitian terdapat $13,7 \%$ underweight, $54,1 \%$ normal, $28 \%$ pre-obese, Obese I sebesar 3,9\%, dan obese II 0,3\%.

2. Berdasarkan pengukuran lingkar perut, didapatkan hasil13,5\% laki-laki obesitas sentral dan $4,1 \%$ perempuan. Dengan kriteria laki-laki $\geq 90 \mathrm{~cm}$, dan perempuan $\geq 80 \mathrm{~cm}$.

\section{SARAN}

Setelah melakukan penelitian dan melihat hasil yang diperoleh, penulis memberikan saran sebagai berikut:

1. Penelitian ini dapat dilanjutkan dengan populasi yang sama dalam jangka waktu beberapa tahun kedepan untuk melihat perbandingan indeks massa tubuh mahasiswa Fakultas Kedokteran Universitas Sam Ratulangi angkatan 2011 pada waktu subyek penelitian baru memulai perkuliahan pendidikan dokter dan setelah beberapa tahun menjadi mahasiswa Fakultas Kedokteran.

2. Penelitian ini dapat dilakukan pada ke- 
lompok populasi lain, seperti pada mahasiswa Fakultas Kedokteran angkatan lainnya, pekerja kantoran, dan populasi lainnya yang mempunyai aktivitas kurang.

\section{DAFTAR PUSTAKA}

1. Soegih R. Obesitas. Jakarta: Sagung Seto, 2009.

2. Arisman. Obesitas, Diabetes Mellitus, Dislipidemia. Jakarta: EGC, 2008.

3. Nelson. Ilmu Kesehaan Anak. Jakarta: EGC, 2000.

4. Harjanto. Diagnosis Fisik. Jakarta: EGC, 2005.

5. Giney J Michael. Gizi Ilmu Kesehatan Masyarakat. Jakarta: EGC, 2009.

6. Damayanti. Obesitas Pada Remaja Dan Anak [Tesis].2006.

7. Sugondo S. Ilmu Penyakit Dalam. Jakarta: Fakultas kedokteran Universitas Indonesia, 2009.

8. Samsudin. Masalah gizi pada anak: Naskah lengkap pendidikan berkelanjutan ilmu kesehatan anak XXXV. Jakarta: Fakultas Kedoktern Univeritas Indonesia, 1995.

9. Kawengian.S. Penentuan Status Gizi dan Survey Konsumsi Makanan. Buku ajar Ilmu Gizi. Fakultas kedokteran Universitas Sam Ratulangi (tidak di publikasi); 2007.

10. Ester M. Penilaian status gizi. Jakarta: EGC, 2002.

11. Sugondo S. Obesitas. Buku Ajar Ilmu Penyakit Dalam. Jakarta: Internal Publishing, 2010.

12. International Diabetes Federation 2005. Metabolic Syndrome Driving the CVD Epidemic [homepage on the Internet]. Nodate [cited 2012 Des 15]. Available from: www.Idf.org.

13. Grundy SM, Hansen B, Smith SC, Cleeman Jl, Kahn RA. Clinical management of metabolic syndrome : Report of the American Diabetes
Association Conference on scientific issues related to management. Circulation. 2004;109:551-556.

14. Hotamisligil GS. Inflammation and Metabolic Disorders. Nature. 2006; 444:860-867.

15. Isomaa $B$, Almgren $P$, Tuomi $T$. Cardiovascular morbidity and mortality associated with metabolic syndrome. Diab Care. 2001;24:683-689.

16. Alberti KGM, Zimmet PZ. Definition, diagnosis and classification of diabetes mellitus and its complications. Part 1: diagnosis and classification of diabetes mellitus. Provisional report of a WHO consultation. Diab Med.1998; 15:539553.

17. Third Report of the National Cholesterol Education Program (NCEP) Expert Panel on Detection, Evaluation, and Treatment of High Blood Cholesterol in Adult (Adult Treatment Panel III) Final Report. Circulation. 2002;106:31343135.

18. International Diabetes Federation 2005. The IDF Consensus Worldwide Definition of the Metabolic Syndrome [homepage on the Internet]. Nodate [cited 2011 Des 15]. Available from: www.Idf.org.

19. World Health Organization (WHO). Obesity. Preventing and managing the global epidemic report of a WHO consultation. Geneva; Switzerland; 1999.

20. Universitas Sriwijaya. Kenali dan kendalikan obesitas; 2011.

21. Kementerian Kesehatan Republik Indonesia. Obesitas Dan Kurang Aktivitas Fisik Menyumbang 30\% Kanker [homepage on the Internet]. Nodate [cited 2011 Des 15]. Available from: Di www.depkes.go.id.

22. Dampak Obesitas [homepage on the Internet]. Nodate [cited 2011 Des 15]. Available from: http://www.stroke bethesda.com. 